\title{
PENGARUH BEBAN KERJA DAN KEJENUHAN KERJA TERHADAP KINERJA KARYAWAN DI UNIVERSITAS KOMPUTER INDONESIA
}

\author{
Yayah Sutisnawati \\ Dr. Ir. Deden A. Wahab Sya'hroni, MSi. \\ Program Studi Magister Manajemen,Fakultas Pascasarjana \\ Universitas Komputer Indonesia
}

\begin{abstract}
ABSTRAK
Tujuan penelitian ini adalah untuk mengetahui pengaruh beban kerja dan kejenuhan kerja terhadap kinerja karyawan Universitas Komputer Indonesia. Total sampling yang digunakan dalam penelitian ini adalah 152 responden. Pengukuran data yang dilakukan menggunakan kuesioner skala Likert. Tekhnik analsisis yang digunakan adalah SEM mengunakan software Lisrel V.8. Hasil uji t menyatakan nilai thitung > t tabel $(1,96)$, kecuali untuk variabel kejenuhan kerja nilai $\mathrm{t}$ hitung $<\mathrm{t}$ tabel. Hasil penelitian menunjukkan bahwa beban kerja berpengaruh signifikan terhadap kinerja karyawan , sedangkan variabel kejenuhan kerja berpengaruh signifikan dengan arah negative terhadap Kinerja .
\end{abstract}

Kata Kunci : Beban Kerja, Kejenuhan Kerja, Kinerja. 


\section{ABSTRACT}

The purpose of this study was to determine the effect of workload and work saturation on the performance of Indonesian Computer University employees. The total sampling used in this study was 152 respondents. Data measurements were carried out using a Likert scale questionnaire. The analytical technique used is SEM using Lisrel V.8 software. The results of the t test state the value of $t$ count> t table (1.96), except for the variable work saturation value $t$ count $<t$ table. The results showed that the workload had a significant effect on employee performance, while the work saturation variable had a significant effect on negative direction on performance.

Keywords: Workload, Job Saturation, Performance. 


\section{PENDAHULUAN}

Kinerja merupakan suatu ukuran keberhasilan pegawai dalam melaksanakan tugasnya. Kinerja pegawai dapat dipengaruhi oleh beberapa faktor seperti beban kerja,dan kejenuhan kerja. Dengan kinerja pegawai yang meningkat ini juga memberikan kontribusi bagi perusahaan. Setiap perusahaan berupaya untuk meningkatkan kinerja pegawainya agar tecapainya tujuan perusahaan.

Salah satu upaya untuk meningkat kinerja pegawai yaitu memberikan beban kerja yang tidak berlebihan. "Beban kerja adalah Sejumlah kegiatan yang membutuhkan keahlian dan harus dikerjakan dalam jangka waktu tertentu dalam bentuk fisik maupun fsikis." (Dhania dalam Putu Melati, 2015: 152). Banyaknya tugas yang diberikan kepada pegawai akan menyebabkan hasil yang kurang maksimal karena keterbatasan waktu dan keterampilan. Beban kerja yang tinggi akan menimbulkan stres dan menyebabkan kinerja pegawai menurun. Menurut Agripa T.Sitepu, (2013:124) mendefenisikan beban kerja sebagai sekumpulan atau sejumlah kegiatan yang harus diselesaikan oleh satu unit organisasi atau pemegang jabatan dalam jangka waktu tertentu. Agripa juga berpendapat jika

Program Studi Magister Manajemen

Fakultas Pascasarjana

Universitas Komputer Indonesia kemampuan pekerja lebih tinggi dari pada tuntutan pekerjaan, akan muncul perasaan bosan.Sebaliknya, jika kemampuan pekerjaan lebih rendah dari pada tuntutan pekerjaan, maka akan muncul kelelahan yang lebih.

Kejenuhan kerja atau Burnout dikenal secara luas dalam dunia kerja dan secara khusus nampak pada profesi bidang pelayanan. "Burnout merupakan suatu keadaan psikologis yang mungkin dialami oleh seorang pekerja yang berpengalaman setelah bekerja untuk suatu periode tertentu." (Togia 2015). Berdasarkan pengertian yagn telah dikemukakan oleh para ahli diatas dapat disimpulkan bahwa kejenuhan kerja atau burnout adalah keadaan yang mencerminkan reaksi emosional yang tengah dirasakan seorang karyawan, dimana dapat ditandai dengan kelelahan fisik, mental dan emosional, serta rendahnya penghargaan terhadap diri sendiri yang menyebabkan seorang karyawan terganggu dan terjadi penurunan pencapaian prestasi pribadi. Burnout dianggap sebagai suatu proses yang digunakan untuk menunjukan kondisi mal-adjustment dalam menghadapi stress kerja yang dialami oleh pekerja dalam bidang pelayanan. Burnout sendiri menekankan terjadinya suatu perubahan motivasi dan hilangnya semangat yang dialami karyawan berkaitan dengan kekecewaan terhadap situasi pekerjaan. 


\section{KAJIAN PUSTAKA}

\section{Beban Kerja}

Beban kerja adalah Suatu kondisi dari pekerjaan dengan uraian tugasnya yang harus diselesaikan pada batas waktu tertentu Tarwaka (2011:106) dalam Kevin F, 2016:109). Menurut Koesomowidjojo, Suci R.Ma'rih (2017:22) beban kerja kuantitatif akan menunjukan adanya jumlah pekerjaan besar yang harus dilaksanakan seperti jam kerja yang cukup tinggi, tekanan kerja yang cukup besar, atau berupa besarnya tanggung jawab yang besar atas pekerjaan yang diampunya.

Faktor yang Mempengaruhi Beban Kerja;

Beban kerja dipengaruhi oleh 2 faktor, yaitu faktor eksternal dan faktor internal. Menurut Aminah Soleman (dalam Arika, 2011:85), faktor-faktor yang mempengaruhi beban kerja adalah sebagai berikut :

1.Faktor Internal, adalah factor yang berasal dari dalam tubuh akibat dari reaksi beban kerja eksternal yang berpotensi sebagai strwssor, meliputi factor somatic (Jenis kelamin, umur, ukuran tubuh, status gizi, kondisi kesehatan dan sebagainya).
2.Faktor Eksternal yaitu factor yang berasal dari luar tubuh pekerja, seperti :

- Tugas (Task) meliputi tugas seperti fisik : Stasiun kerja, tata ruang tempat kerja, kondisi ruang kerja, sikap kerja, beban yang diangkat. Sedangkan tugas yang bersifat mental meliputi : tanggung jawab, Komplektisitas pekerjaan, emosi pekerjaan.

- Organisasi kerja. Meliputi: lamanya waktu kerja, waktu istirahat, sift kerja, system kerja.

- Lingkungan kerja. Lingkungan kerja ini dapat memberikan beban tambahan yang meliputi lingkungan beban kerja fisik, lingkungan kimiawi, lingkungan kerja biologis, dan lingkungan kerja psikologis.

\section{Kejenuhan Kerja}

Berikut ini adalah beberapa pengertian tentang Kejenuhan Kerja yang dikemukakan para ahli, yang diantaranya adalah sebagai berikut :

Maslach (dalam John M Ivansevich, Robert Konopaske dan Michael T. Matteson, 2010) menjelaskan mengenai definisi burnout secara oprasional. "Burnout is a syndrome of emotional exhaustion, depersonalization, and reduced personal accomplishment that occur among individuals who do people work of some kind", yang berdasarkan definisi tersebut maka dapat ditentukan kapan seseorang telah mengalami burnout, dengan meneliti gejala-gejala 
kekeringan emosional, adanya dipersonalisasi dan penurunan rasa keberhasilan dalam melakukan tugas sehari-hari.

Burnout dikenal secara luas dalam dunia kerja dan secara khusus nampak pada profesi bidang pelayanan (Togia, 2005). Burnout merupakan suatu keadaan psikologis yang mungkin dialami oleh seorang pekerja yang berpengalaman setelah bekerja untuk suatu periode waktu tertentu.

Faktor yang Mempengaruhi Kejenuhan:

Kejenuhan Kerja biasanya terjadi karena adanya ketidaksesuaian antara pekerjaan dengan pekerja. Ketika adanya perbedaan yang sangat besar antara individu yang bekerja dengan pekerjaannya akan mempengaruhi performasi kerja. Leiter dan Maslach (dalam Nikki Rasuna, 2011) membagi beberapa faktor yang mempengaruhi munculnya burnout, yang diantaranya adalah sebagai berikut :

\section{Work Overloaded \\ 2. Lock of Work Control \\ 3. Rewarded of Work \\ 4. Breakdown in Community \\ 5. Treated Fairly \\ 6. Dealing With Conflit Values}

\section{Kinerja}

Menurut Harsuko (2011), kinerja adalah sejauh mana seseorang telah

Program Studi Magister Manajemen

Fakultas Pascasarjana

Universitas Komputer Indonesia memainkan baginya dalam melaksanakan strategi organisasi, baik dalam mencapai sasaran khusus yang berhubungan dengan peran perorangan atau dengan memperlihatkan kompetensi yang dinyatakan relevan bagi organisasi. Kinerja adalah suatu konsep yang multi dimensional mencakup tiga aspek yaitu : sikap (attitude), kemampuan (ability), dan prestasi (accomplishment).

Rivai dan Sagala (2009) menyatakan bahwa kinerja perilaku yang nyata yang ditampilkan setiap orang sebagai prestasi kerja yang dihasilkan oleh pegawai sesuai dengan perannya dalam organisasi. Sedangkan menurut Milkovich dan Boudreau (1997) menyatakan bahwa kinerja adalah tingkat dimana pegawai melaksanakan pekerjaannya sesuai dengan syarat-syarat yang telah ditentukan.

Faktor yang Mempengaruhi Kinerja

1) Faktor Kemampuan

2) Faktor Motivasi

\section{METODE PENELITIAN}

\section{Populasi dan Sampel}

Teknik pengambilan sampel dalam penelitian ini adalah total sampling dengan 152 responden. Total sampling adalah teknik pengambilan sampel dimana jumlah sampel sama dengan populasi (Sugiyono, 2009:124). Penelitian populasi yang digunakan adalah karyawan tetap Universitas 
Komputer Indonesia sebanyak 152 responden.

\section{Teknis Analisa Data}

Pengolahan data dalam penelitian ini menggunakan program statistick untuk SEM (Stuctural Equalling Model) dengan Lisrel V.8

\section{Uji Reliabilitas}

Uji reliabilitas digunakan metode Split-Half Method (Spearman-Brown Correlation). Jika nilai Split-Half Method (Spearman-Brown Correlation)> 0,7, maka instrument tersebut dikatakan reliabel. Demikian bila sebaliknya, jika $<0,7$ dikatakan tidak reliabel.

\section{Uji Validitas}

Nilai validitas pada dasarnya adalah nilai korelasi. Oleh karena itu, untuk menguji validitas dilakukan dengan teknik korelasi item total yang merupakan dasar dari korelasi pearson.
Tabel 1

UJI Reliabilitas

\begin{tabular}{|c|c|c|c|c|c|c|}
\hline $\begin{array}{c}\text { Variabel } \\
\text { Laten }\end{array}$ & $\begin{array}{l}\text { Variabel } \\
\text { manifest }\end{array}$ & $\lambda$ & CR & VE & $\lambda^{2}$ & e \\
\hline \multirow{4}{*}{ Beban } & XI.1 & 0,74 & \multirow{4}{*}{0,803} & \multirow{4}{*}{0,506} & 0,548 & 0,452 \\
\hline & XI.2 & 0,75 & & & 0,563 & 0,438 \\
\hline & XI.3 & 0,70 & & & 0,490 & 0,510 \\
\hline & XI.4 & 0,65 & & & 0,423 & 0,578 \\
\hline \multirow{3}{*}{ Kejenuhan } & $\mathrm{X} 2.1$ & 0,75 & \multirow{3}{*}{0,798} & \multirow{3}{*}{0,570} & 0,563 & 0,438 \\
\hline & X3.2 & 0,70 & & & 0,490 & 0,510 \\
\hline & $\mathrm{X} 2.4$ & 0,81 & & & 0,656 & 0,344 \\
\hline \multirow{2}{*}{ Kinerja } & Y1 & 0,79 & \multirow{2}{*}{0,739} & \multirow{2}{*}{0,586} & 0,624 & 0,376 \\
\hline & $\mathrm{Y} 2$ & 0,74 & & & 0,548 & 0,452 \\
\hline
\end{tabular}

Sumber: Hasil Pengolahan Data, 2018

\section{HASIL PENELITIAN DAN PEMBAHASAN}

Hasil perhitungan reliabiltias dapat dilihat pada tabel di atas, menunjukkan bahwa uji reliabilitas untuk variabel Beban Kerja (X1), Kejenuhan (X2), dan Kinerja (Y). menghasilkan nilai baik. Dapat dilihat bahwa nilai Construct Reliability (CR)nya $\geq 0,70$ dan nilai Variance Extract (VE)-nya $\geq 0,50$ untuk masing-masing variabel, sehingga disimpulkan bahwa Beban Kerja (X1), Kejenuhan (X2), dan Kinerja (Y) adalah reliabel. 


\section{Konseptualisasi Model}

Tabel 2

\section{UJI Validitas}

\begin{tabular}{|c|c|c|c|}
\hline Pertanyaan & r hitung & $\begin{array}{c}\text { Titik } \\
\text { kritis }\end{array}$ & Kesimpulan \\
\hline $\mathrm{x} 1.1$ & 0,874 & 0,158 & Valid \\
\hline $\mathrm{x} 1.2$ & 0,936 & 0,158 & Valid \\
\hline $\mathrm{x} 1.3$ & 0,881 & 0,158 & Valid \\
\hline $\mathrm{x} 1.4$ & 0,743 & 0,158 & Valid \\
\hline $\mathrm{x} 1.5$ & 0,904 & 0,158 & Valid \\
\hline $\mathrm{x} 1.6$ & 0,915 & 0,158 & Valid \\
\hline $\mathrm{x} 1.7$ & 0,887 & 0,158 & Valid \\
\hline $\mathrm{x} 1.8$ & 0,871 & 0,158 & Valid \\
\hline $\mathrm{x} 1.9$ & 0,734 & 0,158 & Valid \\
\hline $\mathrm{x} 1.10$ & 0,730 & 0,158 & Valid \\
\hline
\end{tabular}

Sumber: Hasil Pengolahan Data, 2018

Berdasarkan table daiatas, variable beban kerja, kejenuhan kerja dan kinerja masing - masing memiliki nilai koefisien reliabilitas ( $\mathrm{r}$ hitung) yang lebih besar dari 0,7 sehingga disimpulkan bahwa variable beban kerja, kejenuhan kerja dan kinerja masing-masing adalah reliabel. variabel konstruk valid dan reliabel
Tahap ini berkaitan dengan pembentukan model awal model awal persamaan struktural, sebelum dilakukan estimasi. Model awal ini diformulasikan berdasarkan suatu teori atau penelitian sebelumnya. Spesifikasi model penelitian, yang merepersentasikan permasalahan yang diteliti, adalah penting di dalam SEM. Pada penelitian ini, yang menjadi variabel eksogen adalah Beban Kerja $\left(\mathrm{X}_{1}\right)$, Kejenuhan $\left(\mathrm{X}_{2}\right)$ dan variabel endogen nya adalah Kinerja (Y).

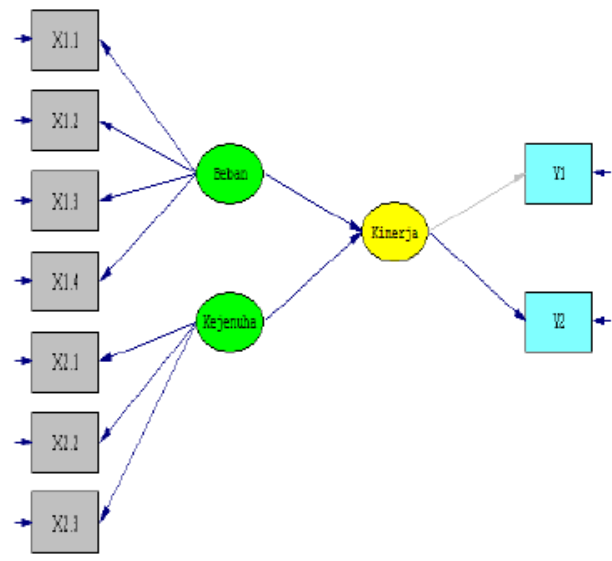

Gambar 4.16 Skema Konseptual

Model 


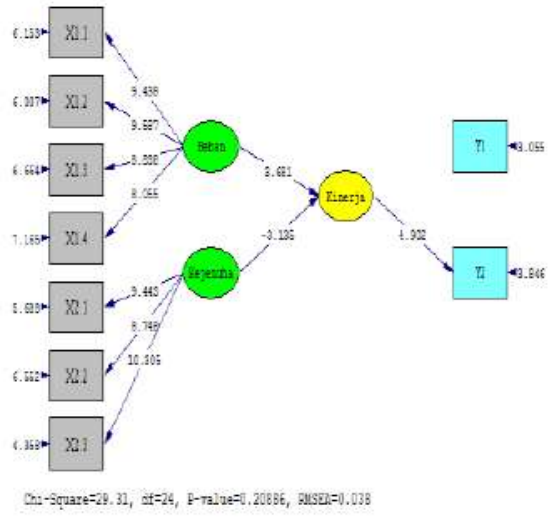

Gambar 4.18

Hasil Estimasi t-values

Berdasarkan gambar di atas, maka diperoleh persamaan struktural untuk model tersebut adalah sebagai berikut:

\section{Structural Equations}

Kinerja $=0.38 *$ Beban $-0.32 *$ Kejenuhan, Errorvar. $=0.72, \mathrm{R}^{2}=0.28$
$(0.10)$
(0.10)
$(0.20)$
3.68
$-3.13$
3.57

Berdasarkan persamaan diatas, dapat disimpulkan sebagai berikut:

1. Koefisien jalur variabel Beban Kerja $\left(\mathrm{X}_{1}\right)$, terhadap Kinerja $(\mathrm{Y})$ adalah 0,38 artinya terdapat hubungan yang rendah antara Beban Kerja $\left(\mathrm{X}_{1}\right)$ dengan Kinerja (Y).

2. Koefisien jalur variabel Kejenuhan $\left(\mathrm{X}_{2}\right)$ terhadap Kinerja (Y) adalah 0,32 artinya terdapat hubungan yang rendah antara Kejenuhan $\left(\mathrm{X}_{2}\right)$ dengan Kinerja (Y).

3. Hubungan antara Beban Kerja $\left(\mathrm{X}_{1}\right)$ dan Kejenuhan $\left(\mathrm{X}_{2}\right)$ memiliki Nilai $R^{2}$ (R squared) sebesar 0,28. Artinya Beban Kerja $\left(\mathrm{X}_{1}\right)$ dan Kejenuhan $\left(\mathrm{X}_{2}\right)$ memberikan pengaruh sebesar 28,0\% terhadap Kinerja (Y), sedangkan sisanya (100\%-28,0\%) sebesar 0,72 atau $72,0 \%$ adalah pengaruh dari variabel lain yang tidak diteliti dalam penelitian ini.

\section{Pengujian Hipotesis Secara parsial}

Pengujian secara parsial dilakukan untuk menguji:

1. Apakah variabel Beban Kerja $\left(\mathrm{X}_{1}\right)$ memiliki pengaruh yang signifikan terhadap Kinerja (Y).

2. Apakah variabel Kejenuhan $\left(\mathrm{X}_{2}\right)$ memiliki pengaruh yang signifikan terhadap Kinerja (Y)

Pengujian ini dilakukan pada model hasil modifikasi setelah didapatkan model dengan fit yang lebih baik.

Adapun hipotesa umum untuk masing-masing pengujian adalah sebagai berikut:

$\mathrm{H}_{0}$ : tidak terdapat pengaruh signifikan

$\mathrm{H}_{1} \quad$ : terdapat pengaruh signifikan

Kriteria uji: 
Tolak Ho jika $t$ hitung $\geq \mathrm{t}$ tabel atau $\mathrm{t}$ hitung $\leq-\mathrm{t}$ tabel

Terima Ho jika $\mathrm{t}$ hitung $<\mathrm{t}$ tabel atau $\mathrm{t}$ hitung $\geq-\mathrm{t}$ tabel

Berikut ini merupakan uji
hipotesa untuk masing-masing
variabel:

Hipotesa kedua: Terdapat pengaruh signifikan Beban Kerja (X terhadap Kinerja (Y)

Hipotesa Statistik:

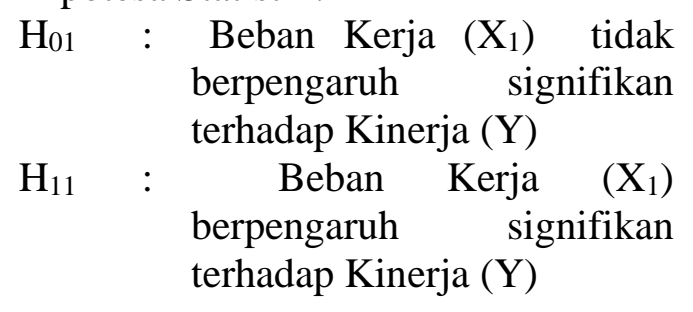
$\mathrm{H}_{11}$ : Beban Kerja $\left(\mathrm{X}_{1}\right)$ berpengaruh signifikan terhadap Kinerja (Y)

Dari hasil perhitungan diperoleh nilai koefisien jalur $\rho_{\mathrm{yx} 1}=$ 0,38 dengan nilai thitung $=3,68$. Nilai koefisien jalur diatas menunjukkan hubungan yang searah antara Beban Kerja $\left(\mathrm{X}_{1}\right)$ dan Kinerja (Y), karena bernilai positif $(0,38>0)$. Artinya jka Beban Kerja meningkat maka Kinerja akan meningkat, begitu juga sebaliknya.

Nilai pada t tabel dengan tingkat signifikansi 0,05 adalah $\pm 1,96$ sehingga $\mathrm{t}$ thitung $(3,68)>\mathrm{t}$ tabel $(1,96)$. Dengan demikian koefisien signifikan, $\mathrm{H}_{01}$ ditolak dan $\mathrm{H}_{11}$ diterima, artinya terdapat pengaruh signifikan Beban Kerja (X1) terhadap Kinerja (Y). Hipotesa kedua: Terdapat pengaruh signifikan Kejenuhan $\left(X_{2}\right)$ terhadap Kinerja (Y)

Program Studi Magister Manajemen

Fakultas Pascasarjana

Universitas Komputer Indonesia
Hipotesa Statistik:
$\mathrm{H}_{02}$ : Kejenuhan $\left(\mathrm{X}_{2}\right)$ tidak berpengaruh signifikan terhadap Kinerja (Y)
$\mathrm{H}_{12}$ : Kejenuhan $\left(\mathrm{X}_{2}\right)$ berpengaruh signifikan terhadap Kinerja (Y)

Dari hasil perhitungan diperoleh nilai koefisien jalur $\rho_{\mathrm{yx} 2}=-$ ,32 dengan nilai t hitung $=3,13$. Nilai koefisien jalur diatas menunjukkan hubungan yang tidak searah antara Kejenuhan $\left(\mathrm{X}_{2}\right)$ dan Kinerja (Y), karena bernilai negatif $(-0,32<0)$. Artinya jika Kejenuhan meningkat maka Kinerja akan menurun, begitu juga sebaliknya.

Nilai pada t tabel dengan tingkat signifikansi 0,05 adalah $\pm 1,96$ sehingga $\mathrm{t}$ thitung $(-3,13)<\mathrm{t}$ tabel $(-1,96)$. Dengan demikian koefisien signifikan, $\mathrm{H}_{02}$ ditolak dan $\mathrm{H}_{12}$ diterima, artinya terdapat pengaruh signifikan Kejenuhan $\left(\mathbf{X}_{2}\right)$ terhadap Kinerja (Y).

\section{Tabel Pengujian Hipotesis}

\begin{tabular}{|l|l|l|l|l|l|}
\hline $\begin{array}{l}\text { Hipo } \\
\text { tesis }\end{array}$ & Jalur & $\begin{array}{l}\text { Koef } \\
\text { isien }\end{array}$ & $\begin{array}{l}\text { T- } \\
\text { stat } \\
\text { isti } \\
\mathbf{k}\end{array}$ & $\begin{array}{l}\text { T- } \\
\text { ta } \\
\text { be } \\
\mathbf{l}\end{array}$ & $\begin{array}{l}\text { Keter } \\
\text { angan }\end{array}$ \\
\hline $\mathrm{H}-1$ & $\begin{array}{l}\text { Beba } \\
\mathrm{n} \\
\text { Kerja } \\
\rightarrow \\
\text { Kiner } \\
\text { ja }\end{array}$ & 0,38 & 3,68 & 1, & $\begin{array}{l}\text { H0 } \\
\text { Ditola } \\
\mathrm{k}\end{array}$ \\
\hline
\end{tabular}




\begin{tabular}{|c|c|c|c|c|c|}
\hline $\mathrm{H}-2$ & $\begin{array}{l}\text { Keje } \\
\text { nuha } \\
\mathrm{n} \rightarrow \\
\text { Kiner } \\
\text { ja }\end{array}$ & $\begin{array}{l}- \\
0,32 \\
0\end{array}$ & $\begin{array}{l}- \\
3,13 \\
5\end{array}$ & $\begin{array}{l}- \\
1, \\
96\end{array}$ & $\begin{array}{l}\mathrm{H} 0 \\
\text { Ditola } \\
\mathrm{k}\end{array}$ \\
\hline H-3 & $\begin{array}{l}\text { Beba } \\
\mathrm{n} \\
\text { Kerja } \\
\leftrightarrow \\
\text { Keje } \\
\text { nuha } \\
\mathrm{n}\end{array}$ & $\begin{array}{l}- \\
0,10 \\
8\end{array}$ & $\begin{array}{l}- \\
1,07 \\
6\end{array}$ & $\begin{array}{l}- \\
1, \\
96\end{array}$ & $\begin{array}{l}\text { H0 } \\
\text { Diteri } \\
\text { ma }\end{array}$ \\
\hline
\end{tabular}

\section{Pengujian Hipotesa secara simultan}

Pengujian secara simultan dilakukan untuk mengetahui apakah variable Beban Kerja $\left(X_{1}\right)$ dan Kejenuhan $\left(\mathrm{X}_{2}\right)$ secara bersama-sama memiliki pengaruh signifikan terhadap variabel Kinerja (Y) .

Hipotesa statistik statistik yang digunakan adalah:

$\mathrm{H}_{03} \quad$ : Beban Kerja $\left(\mathrm{X}_{1}\right)$ dan Kejenuhan $\left(\mathrm{X}_{2}\right)$ secara bersama-sama tidak memiliki pengaruh signifikan terhadap variabel Kinerja (Y).

$\mathrm{H}_{13}$ : Beban Kerja $\left(\mathrm{X}_{1}\right)$ dan Kejenuhan $\left(\mathrm{X}_{2}\right)$ secara bersama-sama memiliki pengaruh signifikan terhadap variabel Kinerja (Y)
Kriteria uji:

- $\quad$ Tolak Ho jika $F$ hitung $\geq F$ tabel

- Terima Ho jika F hitung < F table Untuk menentukan nilai $F$ hitung, maka digunakan rumus sebagai berikut:

$$
\begin{gathered}
\mathrm{F}_{\text {hitung }}=\frac{(152-2-1) \mathrm{R}^{2}}{2\left(1-\mathrm{R}^{2}\right)} \\
\mathrm{F}_{\text {hitung }}=\frac{(152-2-1) \times 0,28}{2(1-0,28)} \\
=28,972
\end{gathered}
$$

Uji statistik di atas mengikuti distribusi $\mathrm{F}$ dengan $\alpha=5 \%$, dengan derajat kebebasan $\mathrm{db} 1=\mathrm{k}=2$, dan $\mathrm{db} 2$ $=\mathrm{n}-\mathrm{k}-1=152-2-1=149$, diperoleh $\mathrm{F}$ tabel $=3,056$. Dari hasil di atas dapat dilihat bahwa $\mathrm{F}$ hitung $\geq \mathrm{F}$ tabel, yaitu $28,972 \geq 3,056$ sehingga $\mathrm{H}_{03}$ ditolak dan $\mathrm{H}_{13}$ diterima, hal ini menunjukkan bahwa Variabel Beban Kerja $\left(\mathbf{X}_{1}\right)$, dan Kejenuhan $\left(\mathbf{X}_{2}\right)$ secara bersama-sama memiliki pengaruh signifikan terhadap variabel Kinerja (Y). 


\section{KESIMPULAN DAN SARAN}

\section{Kesimpulan}

Berdasarkan penelitian yang telah dilakukan mengenai PengaruhVariabel Beban Kerja $\left(\mathrm{X}_{1}\right)$, Kejenuhan Kerja $\left(\mathrm{X}_{2}\right)$, terhadap Kinerja Karyawan (Y), maka peneliti dapat mengambil kesimpulan sebagai berikut

1. Berdasarkan Beban Kerja dan Kejenuhan Kerja terhadap Kinerja Karyawan :

a. Indikator Beban Kerja yang memiliki skor tertinggi adalah mengerjakan tugas dengan baik dan indikator terendah adalah tugas yang diberikan, dengan skor sebesar 5914 dan nilai ratarata 3,9. Maka dari itu dapat kita simpulkan bahwa tanggapan responden mengenai beban kerja secara keseluruhan berada dalam kategori cukup baik.

b. Indikator Kejenuhan Kerja yang memiliki skor tertinggi adalah penurunan prestasi individu dan indikator terendah adalah kelelahan emosional, dengan skor sebesar 5010 dan nilai ratarata sebesar 3,1. Makan dari itu dapat kita simpulkan bahwa tanggapan responden mengenai kejenuhan secara keseluruhan berada dalam kategori cukup baik.

c. Indikator Kinerja Karyawan yang memiliki skor tertinggi adalah faktor motivasi dan indikator terendah adalah faktor

Program Studi Magister Manajemen

Fakultas Pascasarjana

Universitas Komputer Indonesia kemampua, dengan skor sebesar 5132 dan nilai rata-rata sebesar 3.74. Maka dari itu dapat kita simpulkan bahwa tanggapan responden mengenai Kinerja Karyawan secara keseluruhan berada dalam kategori baik.

2. Beban Kerja $\left(\mathrm{X}_{1}\right)$ memberikan pengaruh yang signifikan dengan arah positif terhadap Kinerja (Y) sebesar $16 \%$.

3. Kejenuhan $\left(\mathrm{X}_{2}\right)$ memberikan pengaruh yang signifikan dengan arah negatif terhadap Kinerja (Y) sebesar $12 \%$.

4. Variabel Beban Kerja $\left(\mathrm{X}_{1}\right)$ dan Kejenuhan $\left(\mathrm{X}_{2}\right)$ memberikan pengaruh sebesar $28 \%$ terhadap Variabel Kinerja (Y).

\section{Saran}

Setelah penulis memberikan kesimpulan dari hasil penelitian tentang Pengaruh Beban Kerja dan Kejenuhan Kerja terhadap Kinerja Karyawan di Universitas Komputer Indonesia, maka penulis dapat memberikan saran sebagai berikut :

1. Karyawan merasa Tugas yang diberikan oleh Organisasi kurang sesuai dengan Job Description, sehingga tugas yang 
diberikan tidak dapat diselesaikan tepat waktu. Sebaiknya karyawan diberikan tugas sesuai dengan job description supaya hasil kerjanya dapat maksimal dan selesai tepat waktu.

2. Selain itu, didapati beberapa yang harus diperbaiki dan ditingkatkan perihal kejenuhan kerja, organisasi harus dapat memperhatikan apa yang menjadi kebutuhan karyawan. Diantara kebutuhan yang diperlukan karyawan adalah program liburan (Rekreasi/Family

Gathering), agar karyawan tidak jenuh dalam mengerjakan pekerjaannya.

3. Berdasarkan uraian saran diatas diharapkan masalah yang dihadapi oleh Universitas Komputer Indonesia terkait dengan beban kerja dan kejenuhan kerja dapat diatasi untuk mencapai kinerja Karyawan yang optimal. Dengan cara pembagian kerja sesuai job description dan di laksanakannya program liburan minimal sekali dalam 1 tahun.

4. Diharapkan penelitian ini akan dapat memberikan peluang kepada peneliti lanjutan yang akan meneruskan dan mengkaji faktor-faktor lain yang

Program Studi Magister Manajemen

Fakultas Pascasarjana

Universitas Komputer Indonesia berpengaruh dengan kinerja karyawan yang belum diungkap dan dibahas dalam penelitian yang telah dilakukan ini.

\section{DAFTAR PUSTAKA}

Agripa Toar Sitepu. 2013. Beban Kerja dan Motivasi Pengaruhnya Terhadap Kinerja Karyawan Pada PT. Bank Tabungan Negara Tbk Cabang Manado. Vol.1, No.4, ISSN: 2303-1174.

Aminah Soleman. 2011. Analisis Beban Kerja Ditinjau dari Faktor Usia Dengan Pendekatan Recommended Weiht Limit (Studi Kasus Mahasiswa Unpatti Poka). Vol.05, No.2, ISSN: 1978-1105, Universitas Pattimura.

Azwar, Saifuddin.2012.Realibilitas dan Validitas. Edisi 4. Yogyakarta : Pustaka Pelajar.

Edi Riadi, M.Pd. 2013. Aplikasi Lisrel untuk Penelitian analisis Jalur

Penerbit Andi Yogyakarta.

Freudenberger, Herbert J., and Geraldine Richelson. "The high cost of high achievement." Paperback-Bantam Books (1980). 
Firmansyah Rahma Wahdiniwaty, Deri (2017) Pengaruh

Karakteristik Individu, Beban Kerja dan Lingkungan Kerja Terhadap Kinerja Karyawan pada PT. Sinar Sosro Kantor Penjualan Wilayah (KPW) Jawa Barat Selatan.Jurnal Ilmiah Magister Manajemen, Vol.02. ISSN 2337-5299

Gomes, Faustino Cardoso.2003. Manajemen Sumber Daya Manusia. Yogyakarta; Penerbit Andi.

Gozali., Imam.2009. Aplikasi Multi Variate dengan program SPSS. Semarang Badan Penerbit Universitas Dipenogoro.

Harsuko \& Riniwati.2011. Mendongkrak Motivasi dan Kinerja; Pendekatan Pemberdayaan SDM. Malang; UB Press.

Hengky Latan. 2013. Structural Equation Modeling. Konsep dan Aplikasi .

Menggunakan Program Lisrel 8.80 Penerbit Alfaneta Bandung.

Jonathan , Sarwono.2006. Metode Penelitian Kuntitatif dan Kualitatif. Yogyakarta; PT. Graha Ilmu.

Jansen, Nicole WH, IJmert Kant, dan Piet A. van den Brandt. "Perlu pemulihan dalam populasi yang

Program Studi Magister Manajemen

Fakultas Pascasarjana

Universitas Komputer Indonesia bekerja: deskripsi dan asosiasi dengan kelelahan dan tekanan psikologis." Jurnal internasional obat perilaku 9.4 (2002): 322.

Koesomowidjojo,Suci R.Ma'rih (2017:22) Panduan Praktis Menyusun Analisis Beban Kerja. Raih Asa Sukses, Cet.1 Jakarta 2017

Maslach \& Jackson S.E. 1981. The Measurement of Exsperienced burnout; journal of accupational behavior.2, 99-133.

Mangkunagara, Anwar Prabu. Evaluasi Kinerja. Bandung; Refika Aditama.

Mathis, Robert L., and John H. Jackson. (2001). Manajemen Sumber Daya Manusia. Jakarta; Salemba Empat.

Melati, Ida. 2015. Pengaruh Beban Kerja Terhadap Kepuasan Kerja dengan Stres Kerja Sebagai Variabel Mediasi. Vol.4, No.5, ISSN: 2302-8912.

Milkovich, George T., Johm W. Boudreau.1997. Human Resource Management, USA; Ricard D. Irwin.

Muskamal, 2010. Analisis Beban Kerja Organisasi Pemerintah Daerah. PKP2A II.LAN Makassar.

Narimawati, Umi. 2007. Riset Manajemen Sumber Daya 
Manusia. Jakarta: Agung Media.

O'Driscoll, M., and C. Cooper. "JobRelated Stress and Burnout. Psychology at Work. "Warr, P. London, Penguin (2002): 203-228.

Priansa, Donni Juni. 2014. Perencanaan dan Pengembangan Sumber Daya Manusia. Bandung; Alfabeta.

Rivai, Veithzal dan Sagala, Ella Jauvani. 2009. Manajemen Sumber Daya Manusia Untuk Perusahaan, Edisi Kedua. Jakarta; Raja Grafindo Persada.

Riduwan, 2005.Skala Pengukuran Variabel-variabel Penelitian. Bandung: Alfabeta

Sani, Achmad. 2011. Analisis Pengruh Burnout dan Kecerdasan Emosional Terhadap Kinerja Pegawai PT. Bank Mega Syari'ah Cabang Malang. Malang; Universitas Islam Negeri Maliki Malang.

Savitri Suryandari. 2016. Pengaruh Burnout, Self Esteem Terhadap Kinerja Guru. INOVASI, Volume XVIII, Nomor 1, Januari 2016.
Sugiyono. 2009. Metode Penelitian Kuantitatif Kualitatif dan R\&D. Bandung: Alfabeta.

Sugiyono. 2012. Metode Penelitian Kuantitatif Kualitatif dan R\&D. Bandung: Alfabeta.

Sitinjak J.R.T dan Sugiarto. Lisrel. Yogyakarta. Graha Ilmu

Structural Equation Modeling (SEM). Berbasis kovarian dengan Lisrel dan AMOS. Umi Narimawati \& Jonathan Sarwono. 2017. Jakarta.Penerbit Salemba Empat

Soegoto Soeryanto, Eddy. (2015) Menjadi Pebisnis Ulung.Bandung: Elex Media Komputindo Gramaedia

Sri Widodo Soedarso. 2015. Manajemen Sumber Daya Manusia. Bandung ; Manggu Makmur Tanjung Lestari

Togia, Aspasia. "Measurement of burnout and the influence of background characteristics in Greek academic librarians." Library management 26.3 (2005): 130-138. 


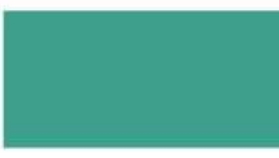

Tarwaka, Bakri. "SH and Sudiajeng, L.(2011)'Ergonomi untuk Keselamatan, Kesehatan Kerja dan Produktivitas'." Retrivieted from http://shadibakri. uniba. ac. $i d / w p-$ content/uploads/2016/03/BukuErgonomi.

Wilson, Bangun. "Manajemen Sumber Daya Manusia." Jakarta: Penerbit Erlangga (2012). 